\title{
How Do Rapidly Internationalizing SMEs Learn? Exploring the Link Between Network Relationships, Learning Approaches and Post-entry Growth of Rapidly Internationalizing SMEs from Emerging Markets
}

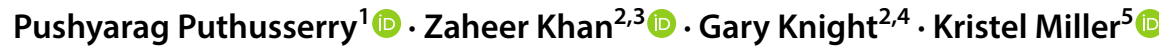

Received: 15 March 2019 / Revised: 1 February 2020 / Accepted: 20 February 2020 /

Published online: 21 July 2020

(c) The Author(s) 2020

\begin{abstract}
This article explores learning among rapidly internationalizing small and medium sized enterprises (SMEs) and how this supports the post-internationalization growth and survival of these firms. We utilize a qualitative multiple case study approach of ten information and communication technology (ICT) SMEs from a key emerging market-India. Findings suggest that during the post-entry stage, rapidly internationalizing SMEs use a wide range of internal and external sources of knowledge. External sources of knowledge include peer networks, associations in the same industry, international clients/partners, and international connections developed through trade fairs and trade missions. Internal sources of knowledge such as self-learning, especially from trial-and-error and experiential efforts, were found to enhance product, market and technological knowledge; and consequently aided geographic and product diversification. The findings also indicate that firms use a mix of integrated, vicarious, congenital and experiential learning approaches in their post-entry growth and survival phases. Experiential and congenital learning were found to be facilitated by firms' internal network sources, whereas external network sources provide an ideal platform for vicarious learning. The study provides new insights into networking and learning by providing evidence that exposure to and connection with diverse types of networks can result in various forms of valuable learning for rapidly internationalizing SMEs, which enhances their post-entry growth.
\end{abstract}

Keywords Rapidly internationalizing SMEs · Networks · Learning · Knowledge · Post-entry growth $\cdot$ Emerging markets

Zaheer Khan

zaheer.khan@abdn.ac.uk

Extended author information available on the last page of the article 


\section{Introduction}

Rapidly internationalizing small and medium-sized enterprises (SMEs) play a significant role in driving economic growth (Trudgen and Freeman 2014; Gerschewski et al. 2018). Accordingly, the strategies used by rapidly internationalizing SMEs continue to attract considerable interest (Oviatt and McDougall 1994; Knight and Cavusgil 2004; Gerschewski et al. 2018). SMEs that internationalize rapidly are called International New Ventures (INVs) (Oviatt and McDougall 1994) and Born Global firms (Knight and Cavusgil 2004; Knight and Liesch 2016). Contrary to the internationalization process model (Johanson and Vahlne 1977), prior research has found that the risk-prone and entrepreneurial nature typical of the founders of INVs and Born Globals tends to support relatively aggressive international expansion (Autio 2005).

It is widely known that SMEs suffer from liabilities of smallness, lack of resources, limited international experience and limited market knowledge (cf. Galkina and Chetty 2015; Johanson and Vahlne 2009), yet paradoxically, many SMEs internationalize rapidly and compete with well-established MNEs. This suggests that SMEs have unique capabilities and value offerings, however, research to date has failed to fully understand the factors of their success (Knight and Cavusgil 2004; Coviello 2015). Studies on internationalizing SMEs have provided important insights about why, when and how they rapidly expand in international markets. In particular, research has stressed the importance of developing capabilities and network relationships to facilitate expansion of SMEs in international markets (Oviatt and McDougall 1994; Fletcher and Harris 2012; Sullivan-Mort and Weerawardena 2006; Khan and Lew 2018). However, little is known on the type of networks SMEs utilize and their role in success-based learning at the post-entry stage (Evers and O'Gorman 2011; Eberhard and Craig 2013; Hånell and Ghauri 2016; Madsen and Desai 2010; Khan and Lew 2018).

Khan et al. (2018) suggest that global networks are important for SMEs based in emerging markets to develop exploratory innovation. Furthermore, knowledge exchanges and learning from peer and international networks enhance the growth and performance of such firms (Kuivalainen et al. 2007; Coviello 2006, 2015; Khan and Lew 2018; Khan et al. 2018); however, to date, there is a lack of empirical research confirming this. Consequently, there is a need for fine-grained analysis of SMEs' post-entry behavior, and how they grow and survive in international markets (cf. Ibeh et al. 2018; Coviello 2015; Khan and Lew 2018). We contribute to this gap by exploring the following research questions: (1) what learning approaches do rapidly internationalizing SMEs' utilize at the post-entry stage? (2) How do learning approaches from various networks affect the postentry growth of rapidly internationalizing SMEs?

To achieve this, we utilize a multiple case study approach to explore rapidly internationalizing SMEs within a knowledge-intensive emerging market context, namely the Indian information and communication technology (ICT) sector, where knowledge and learning are essential to international performance. We examine the acquisition and strategic application of knowledge through learning, 
from both within and outside the enterprise among rapidly internationalizing SMEs, in the context of emerging markets. Such processes represent internal and external learning activities that result in different, yet complementary types of knowledge (Arora and Gambardella 1990; Cohen and Levinthal 1990; Powell et al. 1996). Knowledge developed in this way exerts a differential and synergistic effect that is recognized as an antecedent to innovation (Hartman et al. 1994), firm performance (Bierly and Chakrabarti 1996) and internationalization (Oviatt and McDougall 2005). Prior research calls for the need to extend knowledge on international entrepreneurship in emerging markets (Kiss et al. 2012; Khan and Lew 2018). India is one of the largest emerging markets, in both economic and population terms (Das and Das 2014; Economist 2017). As such, it provides an important context to explore the preceding gaps and research questions.

The research has a number of contributions. First, we respond to calls for research by Tuomisalo and Leppäaho (2019), Sleuwaegen and Onkelinx (2014) and Deligianni et al. (2015) by providing a fine-grained analysis of the learning strategies of rapidly internationalizing SMEs' post-market entry. Second, we provide new insights into the different types of learning approaches (e.g., vicarious, congenital and experiential) (Huber 1991) needed for geographic expansion, market penetration and product development. We extend theory through identifying the importance of knowledge from peers, trade fairs and trial and error as mechanisms for self-learning for SMEs' internationalization and their post-entry growth (Madsen and Desai 2010). Third, although experiential learning plays a central and vital role in the post-entry phase of rapidly internationalizing SMEs, we identity that vicarious and congenital learning are also needed to enhance the scope and speed of their internationalization. Vicarious and congenital learning are important in the early internationalization phase (cf. Bruneel et al. 2010; De Clercq et al. 2012). Thus, our findings emphasizes the role of diverse and integrated learning approaches (e.g., experiential, vicarious and congenital) for post-entry growth of rapidly internationalizing SMEs. We also shed light on how diverse learning is achieved from a wide range of networks. Fourth, we provide important insights into how peer-to-peer learning can alleviate SMEs limited international experience and resources; and provide valuable knowledge for enhancing post-entry growth (e.g., Tuomisalo and Leppäaho 2019; Madsen and Desai 2010). Finally, this research provides a more fine-grained understanding of the need for SMEs to embed themselves within international networks such as trade fairs and trade missions, alongside learning from clients, suppliers and networks to facilitate diverse learning and enhance post-entry growth.

\section{Conceptual Background}

\subsection{The Role of Different Types of Knowledge for Learning During Post-entry Growth of SMEs}

The importance of knowledge and learning in the pre- and post-internationalization phases of firms has been widely acknowledged (Knight and Cavusgil 2004; Knight 
and Liesch 2016; Tuomisalo and Leppäaho 2019). Knowledge has been found to aid rapidly internationalizing SMEs to recognize opportunities, develop offerings and ways of doing business, adapt efficiently and effectively to foreign environments, and become established in new markets (Autio et al. 2000; Gerschewski et al. 2018).

Extant literature emphasizes the need for technological learning within knowledge-intensive businesses in order to identify commercial potential (Clarysse et al. 2011; Deligianni et al. 2015) and understand technological trends. Technological learning can lead to the development of competencies needed to diversify further into international markets (Zahra et al. 2000). Furthermore, Sullivan and Marvel (2011) highlight the value of market and unique product/service knowledge for firms' growth and survival. Prior research identifies the need to explore the interdependent effects of different knowledge types on post-entry growth of rapidly internationalizing SMEs (Sullivan and Marvel 2011; Sleuwaegen and Onkelinx 2014; Deligianni et al. 2015), especially in an emerging market's context. Each type of knowledge will now be discussed.

Rapidly internationalizing firms' product or technology knowledge can be classified into two categories; explorative and exploitative (March 1991). Deligianni et al. (2015) suggest that firms involved in explorative innovation, which creates new technological knowledge and generates genuinely novel products, tend to experience negative growth. In contrast, they find that firms who are exploitative (relying on existing knowledge and product modification) tend to exhibit slow growth (Deligianni et al. 2015). Gabrielsson and Gabrielsson (2013) identify that opportunity creation and explorative learning are more important in the early phases of internationalization, whereas opportunity discovery and exploitative learning are important in later phases. Hsieh et al. (2019) suggest that the creation of new technological knowledge or product exploration can maximize firms' growth opportunities, yet more research is needed to understand how such knowledge is acquired through various networks.

Market and international knowledge have also been found to be important in rapidly internationalizing firms (Deligianni et al. 2015; Pellegrino and McNaughton 2017). Market knowledge on local business partners, their connections, and local institutional situations have been found to aid survival and growth (Eriksson et al. 1997; Gerschewski et al. 2018). Market knowledge influences both exploitative and explorative innovation through enabling the identification of market demands and helps firm's to capitalize on these opportunities (McKelvie and Wiklund 2010: 266). International knowledge has been found to aid the identification and exploitation of opportunities in diverse geographic and product markets (Deligianni et al. 2015) and facilitate not only firm growth but also improve their competitiveness. Despite its importance, the pursuit of internationalization through exploration and exploitation is mostly overlooked in the extant literature (Child et al. 2017).

\subsection{Learning and Post-entry Growth of Rapidly Internationalizing SMEs}

Firms create knowledge through the acquisition, dissemination, interpretation and storage of information from their internal and external environments (Hanvanich et al. 2006; Huber 1991). Learning is an individual and organization-level process 
that cumulatively leads to the development of organizational knowledge (Eisenhardt and Martin 2000; Sinkula et al. 1997; Zhou et al. 2010). Single-loop learning refers to knowledge acquisition that leads to changing strategies, or assumptions underlying strategies, within the firm (Argyris and Schon 1996). Double-loop learning is more encompassing and leads not only to changing strategies and assumptions but also alters basic organizational values and norms that underlie firm strategies (Argyris and Schon 1996).

Prior research suggests that SMEs use both internal and external sources to learn and acquire market, product/technology and international knowledge (Pellegrino and McNaughton 2015). CEOs of rapidly internationalizing firms often have prior international experience and knowledge, which is related to congenital learning (Huber 1991). They also learn through network relationships with key partners or other stakeholders (Bruneel et al. 2010; Park et al. 2015). Entrepreneurs learn vicariously by observing the actions and behaviour of their competitors when they are challenged with insufficient information for learning from their own experience (Huber 1991; Kim and Miner 2007). However, there is a lack of clarity on how different types of learning (experiential, vicarious and congenital learning) aid rapidly internationalizing SMEs post-market entry.

Understanding how organizations learn in international markets is complex (Khan et al. 2018). Learning represents a capability that can provide unique competitive advantages (Teece et al. 1997; Autio et al. 2011). This capability is often developed through a firm's experiential learning (Child et al. 2017), which includes traditional R\&D and technological learning (Zahra et al. 2000) and social (nontechnological) learning. Social learning has been found to arise from misfortunes and mistakes, giving rise to trial-and-error knowledge acquisition, where learning is through the consequences of previous actions (Chandra 2017). Romanello and Chiarvesio (2017) and Tuomisalo and Leppaaho (2019) identify that entrepreneurs transform their organizational knowledge capabilities through applying trial-anderror approaches during the initial, entry, and post-entry stages of new market entry. Trial-and-error learning also plays a crucial role in the exploitation of product and market knowledge (Bingham and Davis 2012).

Studies have noted that firms use internally focused learning to capture diverse knowledge essential to deliver products and services that international markets desire (De Clercq and Zhou 2014; Evers et al. 2012; Weerawardena et al. 2015). In contrast, externally focused learning results through a capacity to build, integrate and reconfigure knowledge generated through external links and institutions. External learning typically arises from the firm's networks (Evers et al. 2012; Fuerst and Zettinig 2015; Park et al. 2015; Tuomisalo and Leppäaho 2019). Mody (1993) and Park et al. (2015) indicate that external learning may constitute inter-organizational learning, through collaborations and partnerships. Networks or collaborations allow firms to gain knowledge on internationalization (Park and Rhee 2012), foreign markets (Fuerst and Zettinig 2015; Presutti et al. 2007; Tuomisalo and Leppäaho 2019; Yu et al. 2011), new opportunities and internationalization paths (Chandra et al. 2012).

Temporary clusters such as trade fairs or business gatherings have been found to be important sources of external learning as they provide opportunities for entrepreneurs to participate in temporary settings where buyers, suppliers, and competitors 
from around the world meet and exchange information (Maskell et al. 2006). Trade fairs can facilitate vicarious learning (Pellegrino and McNaughton 2015; CiszewskaMlinarič et al. 2019) and often lead to acquiring information required for product improvement (product exploitation) and geographic expansion, rather than technological learning (product exploration) (Li 2014).

External networks provide access to foreign market knowledge (Presutti et al. 2007; Gerschewski et al. 2018), client-related information, and knowledge about external opportunities, which all can help SMEs internationalization (Chandra et al. 2012). However, this knowledge is often tacit and complex which can be difficult to transfer from the firm's networks because it requires learning motivation, effort, and ability (Reagans and McEvily 2003). By contrast, simple, codified knowledge can be transferred even if the firm lacks strong network relationships (Reagans and McEvily 2003; Inkpen and Tsang 2005). The process of learning is most efficient where there is knowledge symmetry with a firm's prior knowledge and R\&D investments (Cohen and Levinthal 1990) and if there is a high level of mutual communication between firms (Prashantham and Dhanaraj 2010). For firms engaged in vicarious learning, knowledge is acquired from other, similar firms within their locality that have undergone similar experiences (Fletcher and Harris 2012; Huber 1991; Johanson and Vahlne 2006). This is particularly relevant in the case of emerging market SMEs as they use diverse non-institutional relationship-based ties to overcome the lack of institutional support in their home market (Ciravegna et al. 2014).

SMEs tend to be embedded in idiosyncratic social systems that are interdependent with their industries and focal technologies (Child et al. 2017). SMEs' knowledge domain influences the relationship between information use and network attachment (Child and Hsieh 2014: 605). Rapidly internationalizing firms tend to have a mix of both business/external and personal/internal links (Child et al. 2017). Many such firms depend on technically qualified employees and network links (Salavisa et al. 2012). George et al. (2005) and Child et al. (2017) note that external networks are vital sources of knowledge for rapidly internationalizing companies. Other key sources of technical or product knowledge have been found to be from other similar firms in the region or geographic cluster (Birkinshaw and Hood 2000).

Overall, the importance of collaborating with key stakeholders in order to accelerate the pace of learning (Gabrielsson et al. 2008; Tuomisalo and Leppäaho 2019) and strengthen the learning processes in rapidly internationalizing SMEs (Zou and Ghauri 2010) is widely recognized. But relatively little is known on how peer-firms can support rapidly internationalizing SMEs overcome liabilities of smallness. Furthermore, prior research highlights that better understanding is needed on the role of "trial-and-error" (self-learning) and experiential and vicarious learning in the post-entry internationalization of rapidly internationalizing SMEs (Ciszewska-Mlinarič et al. 2019; Pellegrino and McNaughton 2015; Romanello and Chiarvesio 2017; Tuomisalo and Leppäaho 2019), especially among emerging market firms. Furthermore, the role of learning and different knowledge types utilized by rapidly internationalizing SMEs, especially in emerging markets, needs more attention (Khan and Lew 2018; Gerschewski et al. 2018; Ibeh et al. 2018). There is still a limited understanding regarding the links between different types of knowledge (i.e., product, international and market knowledge) 
and different learning approaches (experiential, vicarious) which can supplement congenital learning (prior experience) in the post-entry stages of rapidly internationalizing SMEs, particularly in the emerging markets' context. Therefore, these concepts will form the basis of our empirical analysis.

\section{Context and Methods}

For this study, we adopted a qualitative, interpretivist multiple case study approach. Qualitative research is appropriate for contexts where the goal is to interpret meaning from actions and experiences (Mason 2017). We conducted our research in the emerging market of India due to it being a high-growth, high-potential economy where it is one of the largest emerging markets (Das and Das 2014; Economist 2017). We chose the software industry due to it being knowledge-intensive, where knowledge is the core competency, suggesting a need for learning (Davis and Eisenhardt 2011). Moreover, India is the world's largest IT and ITES (information technology-enabled services) sourcing destination with a global share of 55\% (NASSCOM 2017).

A multiple case study approach was adopted to explore the existence of multiple realities that are strongly associated with participants' actual experiences (Lincoln and Guba 1985). This approach also responds to calls by Birkinshaw et al. (2011) and Doz (2011) for more qualitative research in international business which promotes theory development in order to develop the field.

A purposeful sampling method was used to identify information rich cases based on a number of characteristics. First, SMEs had to have initiated their international activities instantly or within the first 2 years of their inception in order to be classified as rapidly internationalising. Second, the SMEs had to have entered more than two countries in order to explore the learning processes involved in the post-entry phase of rapidly internationalizing SMEs. Third, we sought for variation in terms of the degrees of their success and entrepreneurs' prior experience. Fourth, we only chose cases where it was possible to conduct in-depth interviews with the founder managers who were directly involved in internationalization and foreign market entry. Table 1 provides an overview of the cases.

Overall, 12 face-to-face semi-structured interviews were conducted across the ten firms (Table 2). In the majority of our cases, only one person had key responsibility for the firm's international business activities. Two of the cases also had a chief marketing officer (CMO) involved in their international expansions, thus it was deemed relevant to include them in the study. Marshall et al. (2013) suggest aligning sample size with comparable studies. Prior comparable qualitative research in this topic have used small sample sizes due to a focus on information richness and fine-grained analysis (for example, Evers and O'Gorman 2011 used 3, Deliganni et al. 2015 used 5 and Khan and Lew 2018 used 8 cases). Therefore, ten cases was deemed relevant to allow for information depth but also sufficient breadth to aid theory development.

We adopted a general interview guide approach (Patton 1990) for each interviewee, which provided a core structure to alleviate validity concerns of collecting 


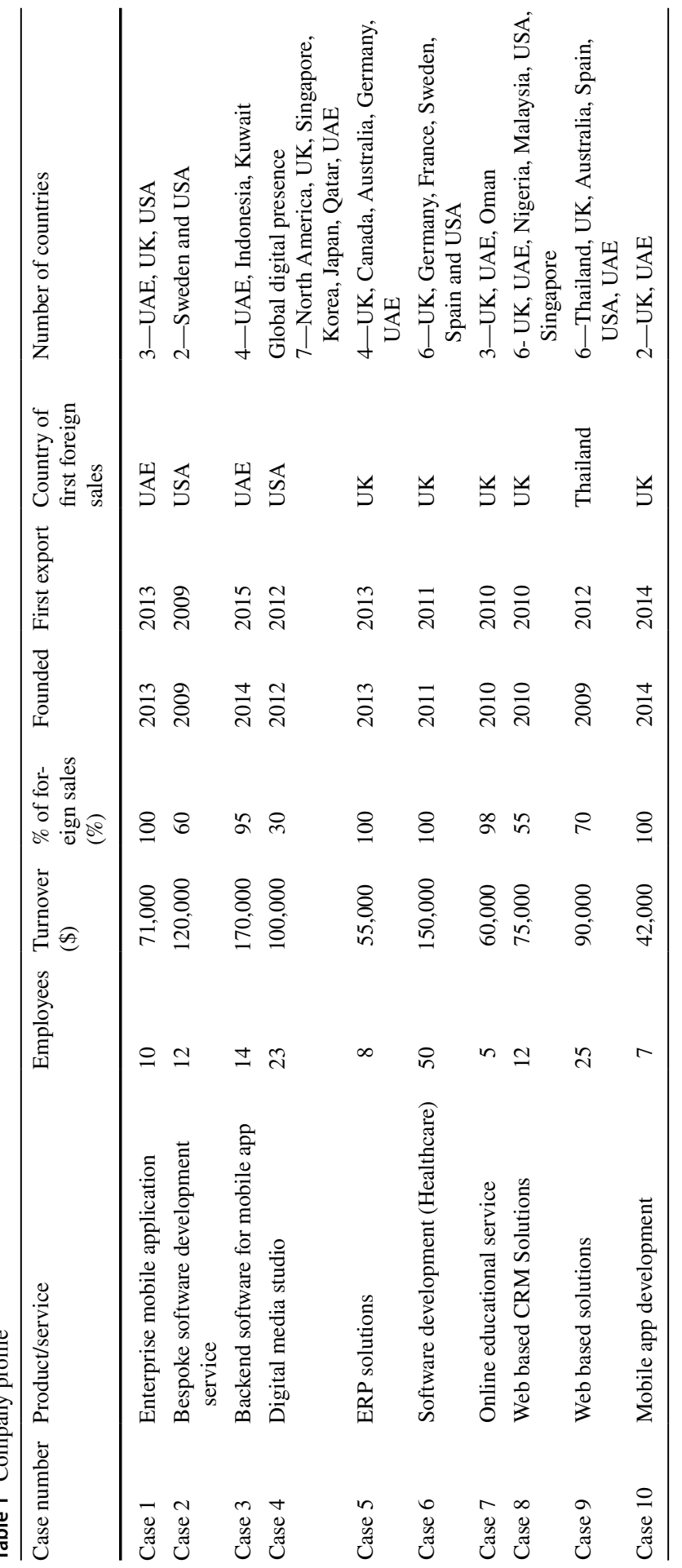




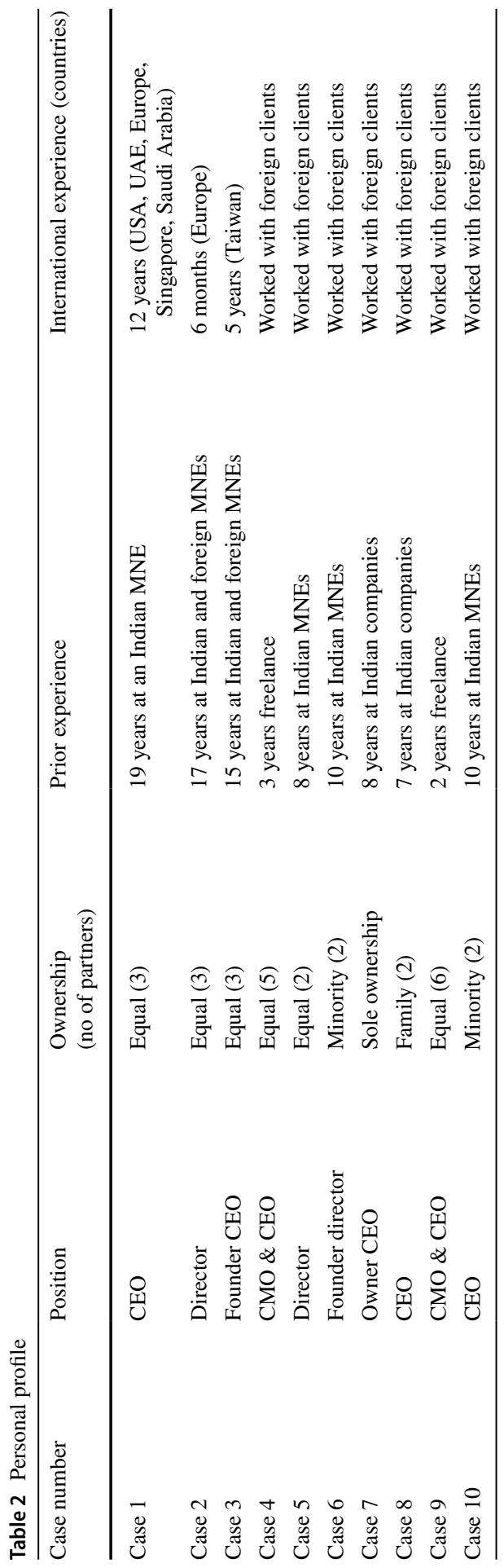


data across cases (Miles and Huberman 1994). This approach also allowed an element of freedom and storytelling where the founding managers could reflect on their internationalization journey to date. The interview collected data on the firm and its entrepreneurial characteristics and explored post-entry strategies. In particular, we focused on the various learning strategies adopted for further growth and survival in the international markets, including the role of various networks. On average, interviews lasted between 45-60 min and were conducted in English, audio-recorded and transcribed verbatim.

The data analysis process consisted of a number of stages (Yin 2009) which involved an iterative approach with constant referral back to literature. This allowed for theory elaboration (Lee 1999) and theory generation (Eisenhardt 1989) in our analysis. First, secondary sources were combined with the interview transcripts in order to develop descriptive narratives of each case facilitating within-case analysis (Eisenhardt 1989). Second, the post-internationalization phase and types of knowledge the cases utilized were identified. Following Deligianni et al (2015), the knowledge types were categorised as being technological, market or international knowledge. Third, emerging patterns related to learning across the post-entry growth and survival stages of the rapidly internationalizing SMEs were then open coded, grouped into 1st order themes and then categorized according to whether the learning approaches were facilitated by internal or external networks. Next, we conducted a cross-case analysis (Miles and Huberman 1994) by comparing the firstorder themes across cases to identify aggregate dimensions and constructs across the cases. Table 3 provides an overview of the data structure.

Table 3 Coding process

\begin{tabular}{|c|c|c|c|}
\hline Open coding & $\begin{array}{l}\text { 1st order themes } \\
\text { Axial coding }\end{array}$ & $\begin{array}{l}\text { Aggregate } \\
\text { dimensions }\end{array}$ & $\begin{array}{l}\text { Type of } \\
\text { learning }\end{array}$ \\
\hline \multicolumn{4}{|l|}{ Geographic diversification } \\
\hline $\begin{array}{l}\text { Interacting and consulting with entrepreneurs who } \\
\text { are doing similar business in the same locality for } \\
\text { product and market knowledge }\end{array}$ & $\begin{array}{l}\text { Peers' network } \\
\text { firms }\end{array}$ & $\begin{array}{l}\text { External } \\
\text { network }\end{array}$ & $\begin{array}{r}\text { Vicarious } \\
\text { learning }\end{array}$ \\
\hline \multicolumn{4}{|l|}{$\begin{array}{l}\text { Observing competitors or other similar firms for } \\
\text { market and international knowledge }\end{array}$} \\
\hline $\begin{array}{l}\text { Participating training and workshops organized by } \\
\text { senior IT professional and consultants in the region } \\
\text { for product, international and market knowledge }\end{array}$ & $\begin{array}{l}\text { Industry associa- } \\
\text { tion }\end{array}$ & & $\begin{array}{r}\text { Vicarious } \\
\text { learning }\end{array}$ \\
\hline $\begin{array}{l}\text { Participating trade fairs or trade mission for market } \\
\text { and international knowledge }\end{array}$ & $\begin{array}{l}\text { International net- } \\
\text { working through } \\
\text { trade fairs and } \\
\text { trade mission }\end{array}$ & & $\begin{array}{r}\text { Vicarious } \\
\text { learning }\end{array}$ \\
\hline $\begin{array}{l}\text { Experience of working in a foreign country or work- } \\
\text { ing with international clients- important for both } \\
\text { international and market knowledge }\end{array}$ & Prior experience & $\begin{array}{l}\text { Internal } \\
\text { network }\end{array}$ & $\begin{array}{c}\text { Congenital } \\
\text { learning }\end{array}$ \\
\hline $\begin{array}{l}\text { Personal relationships with first foreign client } \\
\text { Connections provided by family and friends }\end{array}$ & Social network & & $\begin{array}{l}\text { Experiential } \\
\text { learning }\end{array}$ \\
\hline $\begin{array}{l}\text { Trial and error through internet and digital platforms } \\
\text { for international and market knowledge }\end{array}$ & Self-learning & & $\begin{array}{l}\text { Experiential } \\
\text { learning }\end{array}$ \\
\hline
\end{tabular}


Table 3 (continued)

\begin{tabular}{|c|c|c|c|}
\hline Open coding & $\begin{array}{l}\text { 1st order themes } \\
\text { Axial coding }\end{array}$ & $\begin{array}{l}\text { Aggregate } \\
\text { dimensions }\end{array}$ & $\begin{array}{l}\text { Type of } \\
\text { learning }\end{array}$ \\
\hline \multicolumn{4}{|l|}{ Product diversification-market penetration (exploitation) } \\
\hline $\begin{array}{l}\text { Clients provide product specifications and information } \\
\text { on market potential }\end{array}$ & International clients & $\begin{array}{l}\text { External } \\
\text { network }\end{array}$ & $\begin{array}{r}\text { Vicarious } \\
\text { learning }\end{array}$ \\
\hline $\begin{array}{l}\text { Vicarious learning of observing competitors for } \\
\text { understanding about product, market conditions and } \\
\text { potential }\end{array}$ & Peers' network & & $\begin{array}{c}\text { Vicarious } \\
\text { learning }\end{array}$ \\
\hline \multicolumn{4}{|l|}{$\begin{array}{l}\text { Consulting with other entrepreneurs for product } \\
\text { knowledge }\end{array}$} \\
\hline $\begin{array}{l}\text { Experience and opportunities provided by digital } \\
\text { medium gave confidence for entrepreneurs to follow } \\
\text { trial and error approach to adapt their products for } \\
\text { foreign markets }\end{array}$ & Self-learning & $\begin{array}{l}\text { Internal } \\
\text { network }\end{array}$ & $\begin{array}{l}\text { Experiential } \\
\text { learning }\end{array}$ \\
\hline \multicolumn{4}{|l|}{ Product diversification—product development (exploration) } \\
\hline $\begin{array}{l}\text { Partner provided market information, product specifi- } \\
\text { cations and support for resource adaptations }\end{array}$ & Foreign partner & $\begin{array}{l}\text { External } \\
\text { network }\end{array}$ & $\begin{array}{l}\text { vicarious } \\
\text { learning }\end{array}$ \\
\hline $\begin{array}{l}\text { Market and technology information from IT profes- } \\
\text { sionals }\end{array}$ & Industry experts & & $\begin{array}{l}\text { vicarious } \\
\text { learning }\end{array}$ \\
\hline $\begin{array}{l}\text { Entrepreneurs/employees prior experience provided } \\
\text { them knowledge and understanding about the tech- } \\
\text { nology and market }\end{array}$ & Prior experience & $\begin{array}{l}\text { Internal } \\
\text { network }\end{array}$ & $\begin{array}{r}\text { congenital } \\
\text { learning }\end{array}$ \\
\hline $\begin{array}{l}\text { Research and development team provide product/tech- } \\
\text { nology related information }\end{array}$ & $R \& D$ & & $\begin{array}{l}\text { experiential } \\
\text { learning }\end{array}$ \\
\hline
\end{tabular}

\section{Findings}

The findings revealed that all case firms were highly international in nature, with the majority of their revenue coming from foreign sales. The founders of all cases identified that their companies were developed with the intention of targeting international markets from their inception. Consequently, their primary focus was on rapidly entering foreign markets. The primary motivation for this was to capitalize on the opportunities provided by efficient workforces in Indian IT and ITES sectors.

The data revealed the various internal and external learning approaches which were adopted by the rapidly internationalizing Indian SMEs during their post internationalization growth stages. The rapidly internationalizing SMEs growth stages included both geographic and product diversification. The knowledge utilized and the learning processes within each of these stages will now be discussed.

\subsection{Geographic Diversification}

The interviews identified that both international and marketing knowledge were essential in aiding geographic expansion of the rapidly internationalizing SMEs. Furthermore, both external and internal learning approaches facilitated the 
case firms to acquire and utilize these types of knowledge. The external learning approaches included learning from peers, industry associations, trade fairs and trade missions. The internal learning approaches included prior internationalization experience and a trial and error approach. Each of these approaches to learning will now be explored.

\subsubsection{External Network Sources for Learning}

Learning from peers: Peer learning was found to be invaluable to understand and overcome the challenges and uncertainties in the market that the SME had entered. It was reported that informal knowledge exchange with organizations within the same locality who were in a similar area of business aided the case firms to obtain both product and market knowledge. A CEO of a mobile application company indicated; "Other entrepreneurs doing similar business in the locality [India] are often helpful...sharing ideas regarding their experience in overcoming the challenges and strategies they have used are always very helpful. This happens during the informal meetups, such as meeting at a coffee shop or bumping into each other at some events or even on streets, etc.".

These informal meetings were an important mechanism to both offer and obtain guidance and support on how to further grow within the international market. The founder of a digital marketing company highlighted that "Experiences are shared and we also help each other by referring clients...for example_-a client wants some services which we don't offer, but we know another company which does this, we refer them directly".

It was reported that vicarious learning through observing peers and/or competitors was the easiest way of obtaining knowledge of the process and potential challenges in the market they were intending to enter. For example, the director of a software development company explained: "Before we enter a new market, we always examine the other companies who have already entered that market to see if they faced any challenge and how they dealt with it. We also study how firms dealt with failures and setbacks. This is the easiest and cheapest way to learn about the market, how to enter there, what are the various requirements in that market".

The need for more formalized opportunities for collaboration was identified as being instrumental in aiding peer learning to help SMEs in the Indian IT and ITES sector to grow both domestically and internationally.

Industry associations: The managers of the case firms identified the importance of an IT industry association in the area to alleviate some challenges and uncertainties faced in the domestic and international markets. These associations are run by IT entrepreneurs and provided a platform of support and learning through workshops tailored at small and young firms. These workshops cover topics ranging from introducing new technologies and products to providing specific market-related information. Furthermore, IT entrepreneurs act as informal mentors. The CEO of a mobile application company mentioned that: "It's an informal organization...formed mainly with the intention of helping small and young firms who lack resources and experience... The senior professionals are very experienced and always share their experience- both success and failures. It is helpful for us to foresee and prepare for potential challenges". 
International networking through trade fairs and trade missions: Participating in international trade fairs and trade missions organized by local trade associations or IT clusters was another key source of learning. The industry associations often helped the SMEs take advantage of these learning opportunities. A cloud application developer said: "Trade associations help small companies like us to participate in the big IT /mobile fairs abroad. We go as a team, which is always good to gain better visibility and access. We can join them if we want. It's a great place to update ourselves about the trends in technologies, markets, and learning about potential collaborators". International networking through trade fairs and trade missions was vital for resource-constrained rapidly internationalizing SMEs. Concurring with extant studies, trade fairs and missions were found to provide useful tacit and 'remote' knowledge from international experts which is not available through local networks (Maskell 2014; Li 2014) and introduced vital network channels for emerging market firms which are rapidly internationalizing (Measson and Campbell-Hunt 2015; Maskell 2014).

Exposure to host countries, observing peers and knowledge spillovers from conversations with fellow SMEs' managers was a vital source of indirect vicarious learning for SMEs. For example, a CEO of a web application development company said: "trade fairs are a very good opportunity to see what other people are doing, what are the trends in the market". The trade missions were also reported to lead to domestic learning benefits through reciprocal international trade delegations visiting India.

\subsubsection{Internal Network Sources for Learning}

Prior international experience: It was evident from the findings that prior international experience had helped many of the case firms to develop learning capabilities which cumulatively helped them to learn about further foreign markets. Prior experiential knowledge resulted in skills to negotiate and interact with foreign clients and enhanced their understanding of different work practices. All this helped to bridge the cultural gap. The director of an e-commerce service provider mentioned that: "My experience helped me understand about foreign clients' expectations. They always look for transparency and this is a real issue with the Indian start-ups. For example, some people will under-price their product-sometimes to get an order. It may lead to chaos...they wouldn't normally be able to supply quality products on time if they under-price it. They support you if you are honest and open...they will allow us to outsource or even give us time to develop the capabilities".

Prior experience was suggested by the managers to be crucial for not only entering a market but to develop trust and sustain relationships with foreign clients. The CEO of a cloud application development company with around 20 years of international experience with a leading MNE indicated that: "I can't say my experience as such has helped me in terms of marketing but that exposure helped me in relationship building and gave me the confidence to deal with foreign clients. I know how to deal with them and what they expect". Furthermore, prior experience resulted in first-hand international and market knowledge which included how to adapt resources and capabilities to engage in international operations, how to enter a new 
market and identifying potential clients/suppliers. However, it was stressed that prior experience alone was insufficient for possession of more intrinsic foreign market knowledge.

Social network: Relationships with foreign clients, and prior working relationships and friends and family (ethnic ties) were found to be another important source of international, market and product knowledge required for geographic expansion. A manager from a software development firm highlighted: "My friends, former colleagues and acquaintances who are living in foreign countries were helpful connections in those countries. They are expatriate Indians living in countries like Sweden, the US, and the Middle East. A few of them have their own start-ups...they either directly get their projects done through us or they refer their clients to us if they are not into the software development business. They provided product specifications, information on clients, what changes to make to our products, how to do business in those countries, etc.". Furthermore, personal connections were reported to be important to obtain client information and introductions. The interviewees identified that the connections of their first foreign partner was crucial for their further geographical expansion.

Self-learning: Many of the firms reported that they follow a trial-and-error approach to learn and access new markets. This was found to be particularly prevalent if an organization did not have any network relationships in that particular market and/or lacked prior internationalization related experience. Internet resources also presented them with opportunities to learn about new markets and contact potential customers. A CEO of a mobile application development firm mentioned: "We learn during the course of doing business with multiple clients across countries. We do online searches ...there was no other source. We burned our fingers a few times. Getting a client and understanding their credibility are the main challenges, especially if you do not have any personal connections or you cannot get any references about the clients".

It was evident that online sources of knowledge were a key source of learning for internationalizing resource-constrained emerging market SMEs. However, some respondents highlighted that informal entrepreneurial groups on social network sites like WhatsApp often were unhelpful.

\subsection{Product Diversification}

The findings indicated that continuous innovation and modifications of products were important to sustain post-entry survival due to the highly dynamic and transient nature of their industry. Following March (1991), product diversification within the cases was viewed from the exploration and exploitation perspective. This can be suggested to align with Ansoff's (1957) market penetration (exploitation) and product development (exploration) strategies. It was found that the firms were mainly following product modification or exploitative innovation to penetrate further into their existing market. The findings suggested that rapidly internationalizing SMEs preferred to have an established presence across a small number of countries 
rather than in several regions. This strategy was reported to be important in order to overcome the liabilities of smallness and newness (e.g., Aldrich and Auster 1986).

Moreover, the firms were mainly involved in developing their existing products to be more cost-effective. Similar to geographic diversification, the firms used both internal and external sources to acquire the knowledge required for their product diversification. However, they did not appear to follow a systematic approach to obtain knowledge for their market penetration strategies. This will now be explored.

\subsubsection{External Network Sources of Learning for Market Penetration (Exploitation)}

International clients/customers: When the case firms followed an exploitation approach, international clients emerged as key sources of knowledge. It was identified that the firms were often reactive to clients' requirements and specifications and modified their products accordingly. This was important to maintain client relationships and sustain business in foreign markets. The founder of an ERP development company highlighted that: "We get information mainly from our clients. If they want a new software/application, their IT manager will inform us about it and provide their specification. We then start our own research about it. It is mutual work".

Learning from peers: Firms with similar characteristics were found to be a vital source of post-entry stage learning. Case firms vicariously learned from peers or competitors. For example, one of the managers mentioned that: "One of our founders saw an animated explainer video of a competitor and suggested that we should also try that here... We did our research and developed it gradually. Whenever we do something, we add new things and see how it works. We developed it through our own processes".

Peer learning was reported to be a source of technological knowledge either through direct consultation with the peer firms or indirectly through observing or imitating other firms. Peer learning was suggested to be more common for product exploitation than exploration. The firms referred to the WhatsApp groups of peers as being a good resource to learn about new market conditions, check about potential clients and to keep up to date with risks. The founder of an educational software development firm said: We are part of a global industry and most of us work with foreign clients so it is the easiest way to learn about potential clients.

\subsubsection{Internal Network Sources of Learning for Market Penetration}

Self-learning was found to be the main internal source of learning for firms that are involved in market penetration or exploitation. The majority of cases reported that their prior experience in the industry helped them understand industry dynamics and client requirements. This led to increased confidence to conduct their own independent research and make necessary changes to the products. An owner of a digital App development company said: "If we update a feature in the app or come up with new technology, clients always appreciate and value that. It is mainly our search. We search online and update ourselves...Sometimes we get to know about the new 
technology when we watch some online advertisements, like YouTube. We observe all these and use whenever we can".

Digital magazines and trade-related websites were important sources of updates on new technologies/products. However, many SMEs' managers noted their prior experience helped them understand and assimilate online information to decide how to incorporate new knowledge into their product or operations.

"We download online information and see how we can develop that here...we always want to be one step ahead and therefore we always try to develop a better product than what's available in the market... We have to achieve a certain market share before competitors copy our product. We have to be quick. We give it to some reliable clients for their feedback" (Case 3).

\subsection{Internal Sources of Knowledge for Product Development (Exploration)}

Only two out of ten sampled companies used exploration as a product diversification strategy, which was suggested to be due to the case firms not being involved in developing any proprietary products or technology. The majority of the firms were software developers providing service to mobile or digital companies. The two firms involved in product exploration also highlighted that prior experience and network relationships provided them with key sources of knowledge. A founder of a software development company indicated that: "We have been working in this area for some time and have good knowledge about it... We also consult with senior IT professionals here...they are like mentors. They have good experience and connections in the industry...they know the market and technology very well. We also have our R\&D team, we meet and exchange our ideas regularly, employees also contributed a lot... we also contact trade agencies and other industry experts as well."

\section{Discussion and Conclusions}

This article set out to explore the learning approaches rapidly internationalizing SMEs' utilize during post-entry and how these learning approaches impact their post-entry growth. Our findings provide much needed rich insights into a nascent emerging market context which to date has been underexplored. The findings provide new insights into the post-internationalization learning processes of rapidly internationalizing SMEs. Our findings reveal that rapidly internationalizing SMEs can overcome liabilities of smallness and foreignness and grow post-market entry through effectively developing and leveraging internal and external learning capabilities. Indeed, all cases propensity to learn, post-market entry, aided knowledge acquisition to not only survive in the market but to grow through geographical diversification and product innovation; which were both found to be key drivers of postmarket entry success. Hence our first proposition is:

Proposition 1: Among rapidly internationalizing SMEs, managers leverage knowledge acquired from internal and external sources in order to undertake 
early Internationalization, optimize internationalization performance and product innovation.

While prior research has emphasized the role of networks, the scholarly enquiry has focused on social capital residing solely within the SME, with a lack of research into different types of knowledge gained through external networks (Tuomisalo and Leppäaho 2019). Our findings extend SME internationalization literature by showing the processes through which rapidly internationalizing SMEs acquire knowledge from various internal and external sources of knowledge. Consequently, we extend emergent literature on the internationalization processes of rapidly internationalizing SMEs (Pellegrino and McNaughton 2015) by providing empirical evidence justifying the need for different types of learning approaches and corresponding knowledge for different types of post-entry growth trajectories.

We found that growth through geographic expansion and market penetration requires different types of learning approaches and knowledge. The case firms highlighted the importance of different combinations of knowledge for post-entry growth. For example, international and market-specific knowledge was found to help complement their technological knowledge in order to be able to grow through geographical diversification. This extends existing knowledge through identifying the need for combinative knowledge configurations for different patterns of post-market entry growth (Deligianni et al. 2015; Sullivan and Marvel 2011). The case firms reported that they primarily seek market and product knowledge for market penetration strategies as it allows them to understand customers' demands and requirements. Our cases also revealed the added importance of international knowledge such as market conditions, institutions and resource adaptation which leads to product development through research and development. Extending research by Deligianni et al. (2015) and Pillegrino and McNaughton (2017), international knowledge, particularly knowledge of the target market, was found to enhance alertness towards opportunities in the marketplace which was associated with geographical and product diversification. Therefore, we present our next three propositions:

Proposition 2: Market knowledge-knowledge on potential customers, distribution channels and how to market offerings in the target market-is a key driver of enterprise performance in foreign market entry, geographic expansion and product innovation for rapidly internationalising SMEs.

Proposition 3: Possession of international knowledge, especially specific knowledge of target markets, is a key driver of rapidly internationalizing SMEs' performance in foreign market entry, geographic expansion and product development.

Proposition 4: Possession of product/technological knowledge-knowledge associated with product, technology and/or process - is a key driver of rapidly internationalizing SMEs' performance in foreign market entry, geographic expansion and market penetration.

It also emerged that external sources of knowledge such as peer networks, associations in the same industry, international clients/partners, and international connections developed through trade fairs and trade missions are imperative for 
geographical expansion within international markets (e.g. Li 2014). Our findings did not identify trade fairs or industry associations as being a key source of learning for product diversification. Learning approaches for market penetration of diversified products largely arose from international clients, peer firms and personal relationships (external knowledge). Clients or external partners were primary knowledge sources for product modification and other forms of innovation (e.g., Child et al. 2017). Such approaches helped the rapidly internationalizing SMEs obtain market and product/technological knowledge for market penetration strategies. Indeed, the SMEs relied upon market and technological knowledge to grow through being reactive to customer trends. Being responsiveness to customers needs is important within an emerging and developed market in order to gain a competitive advantage (Luo 2001). This leads to our fifth and sixth propositions:

Proposition 5: External learning related to geographic expansion consists primarily of learning from peers, industry associations, trade fairs, and trade missions; and is mainly achieved vicariously which then enabled the postentry growth of rapidly internationalizing SMEs.

Proposition 6: External network sources of learning, especially of international clients, peers and partners, is a key driver of continuous product innovation, needed to sustain post-market entry performance of rapidly internationalizing SMEs.

Within the case firms, the overall network relationships influenced their postmarket entry strategies and facilitated learning related to internationalization capabilities and strategies. Indeed, network learning emerged as an externally-focused learning capability (Tuomisalo and Leppäaho 2019), which contributed to the development of knowledge that facilitates internationalization and key international activities. Network relationships supported the acquisition of knowledge on internationalization and appeared to help managers reduce uncertainty about operating in foreign markets, which is especially vital to resource-constrained internationalizing SMEs. In particular, our findings emphasized learning that occurs via the organizations' network connections of firms and other organizations within the same industry, known as 'peer learning' (Zahra et al. 2018).

Learning through the firm's networks was found to be dynamic and gave rise to new competencies, and/or renewed existing competencies which are beneficial in turbulent conditions characteristic of rapidly evolving industries and markets, such as the emerging Indian market. Here, 'dynamic' evokes work on dynamic capabilities where capabilities that facilitate renewing competencies to achieve congruence with evolving environmental conditions are especially important (e.g., Teece et al. 1997). Based on the above discussion, we suggest the following propositions:

Proposition 7: Among rapidly internationalizing SMEs, external learning is a key driver in the development of knowledge to manage risk, uncertainty, and challenges in the target market.

Proposition 8: Among rapidly internationalizing SMEs, external learning is a key driver in the development of knowledge to support post-market entry learning and performance in the target market. 
In general, internal learning is critical to successful SME internationalization. The CEO/entrepreneurs' prior experience, networks and self-learning appear to be the key learning component that supports internationalization and post-entry performance among rapidly internationalizing SMEs. Our sampled firms reported that they were able to leverage their learned capabilities which influenced their internationalization and product development. In other words, international entrepreneurial orientation (Covin and Miller 2014) influenced product development amongst the internationalizing SMEs. Our findings suggest that congenital knowledge supports the acquisition and assimilation of new knowledge and its transformation into firms' existing knowledge base. Internal learning, e.g., through trialand-error and self-learning approaches, typically feature an experiential quality. Throughout the cases, it emerged that self-learning or trial and error approaches not only provide product and market knowledge but can aid internationalization knowledge. Consequently, self-learning and trial and error approaches are important for product development, geographic expansion, and superior performance in foreign markets (Romanello and Chiarvesio 2017; Tuomisalo and Leppäaho 2019). This suggests that:

Proposition 9: Among rapidly internationalizing SMEs, internal learning consists primarily of knowledge acquired through prior internationalization experience, personal networks, self-learning, and trial-and-error approaches.

However, the findings did stress the importance of external learning from peers and the internal trial and error approach in order to acquire knowledge of all types for both geographic expansion and market penetration. We found that self-learning, through trial and error, allowed rapidly internationalizing SMEs to maintain their growth trajectories through the development of learning capabilities where they developed market, technology and international knowledge (i.e., Ciszewska-Mlinarič et al. 2019) which was internalized and cumulatively led to new capabilities and knowledge which they could apply in the future (Knight and Cavusgil 2004). Internal learning, e.g., through trial-and-error and self-learning approaches, typically feature an experiential quality and are important for market and international learning, geographic expansion, and superior performance in foreign markets (Madsen and Desai 2010). Hence our next proposition is:

Proposition 10: Self-learning supports the development of product, market and international knowledge, and is a key driver of rapidly internationalizing SMEs' performance in foreign market, product innovation and geographic expansion.

The findings revealed that during post-entry growth and survival phases, firms used mixed integrated vicarious and experiential learning approaches (Sardana and Scott-Kemmis 2010), where knowledge is acquired through second-hand experience by observing network associates alongside existing experiential knowledge (cf. Huber 1991). Various interactions with external associates appeared to strengthen knowledge connections and facilitate vicarious learning. 
Firms engaging in vicarious learning, learn from each other. The end result was that knowledge from both the focal firm and its network was blended and augmented, resulting in distinctive new knowledge capabilities that provided competitive advantages. Concurring with Ciszewska-Mlinarič et al. (2019), vicarious learning led to the acquisition of second-hand experiential knowledge through observing or imitating external stakeholders who have undergone similar experiences. This finding sheds new light on the value of vicarious learning and demonstrates the importance of learning for post-entry internationalization of rapidly internationalizing SMEs.

Furthermore, congenital knowledge (cf. Huber 1991), i.e., knowledge available at the organization's birth-through entrepreneurs' prior experience, was important for both geographic diversification and product development. Prior international experience was found to be a key learning component that supported internationalization and performance among internationalizing SMEs (Child et al. 2017). The findings suggest that such congenital knowledge supports the acquisition and assimilation of new knowledge and its transformation into firms' existing knowledge base. This highlights the importance of the CEOs' or entrepreneurs' prior experiences and knowledge in rapidly internationalizing SMEs, i.e., international entrepreneurial orientation. Therefore, we suggest the following final proposition,

Proposition 11: Among rapidly internationalizing SMEs, experiential and congenital learning was found to be mainly facilitated by firms' internal network sources, whereas vicarious learning was enabled by their external sources.

Entrepreneurial experience and the firm's relationships with partners, professional agencies, research institutes and own R\&D initiatives influenced the acquisition of proprietary knowledge which contributed to their product development strategies. As already identified, SMEs can utilize and gain valuable learning through knowledge transfer from their peers operating within the same industry. Similar to Huber's (1991) grafting, case firms acquired knowledge from their external networks which was not formerly obtainable within the case organization. Such knowledge was said to be critical in helping SMEs internationalize through being an important source of bonding and bridging social capital (Prashantham and Young 2011). Overall, our findings provide important insights into the learning approaches rapidly internationalizing SMEs' utilize during post-entry and how these learning approaches impact post-entry growth.

\subsection{Theoretical Implications}

Taking into account Sleuwaegen and Onkelinx (2014)'s calls for an appreciation of using strategic approaches to better understand the knowledge-based view, we have highlighted how using a strategic perspective will advance understanding about the different growth patterns of rapidly internationalizing SMEs from emerging markets. We identify the need to adopt different approaches to knowledge acquisition from diverse networks and identify the types of knowledge diverse networks can provide. Our findings extend extant literature, which 
has tended to focus on one type of knowledge for firms' growth (Deligianni et al. 2015) by shedding knowledge on the importance of different combinations of knowledge in order to drive internationalizing SME growth through different forms of post-entry geographic and product diversification (market penetration and product development) strategies. As such, findings suggest that there is no 'one size fits all' approach to understanding how rapidly internationalizing SMEs act within the post-entry stage of their internationalization. Moreover, we highlight the importance of the hitherto under-researched role of peer-to-peer learning and its importance within the specific context of rapidly internationalizing SMEs from emerging markets. This type of learning can be used by SMEs seeking to maintain and then grow their market positions following a period of rapid internationalization. Furthermore, rapidly internationalizing SMEs appear to gain valuable knowledge from international trade fairs and trade missions, which enables their growth at the post-entry stage. Thus, we advance knowledge on temporary clusters such as trade fairs and their role in enhancing the post-entry growth of rapidly internationalizing SMEs (Maskell 2014).

Our findings underscore that early internationalization and operating in multiple markets offer growth opportunities, and that post-market entry success hinges on learning and learning-driven innovativeness. Such businesses may well benefit from the 'learning advantage of newness,' which facilitates flexibly adapting their approaches to conditions in foreign markets (Autio et al. 2000). Younger firms are mainly internationally-focused, so they deal more carefully with their foreign exchange partners/clients and learn more from them and build their new international competencies (De Clercq et al. 2012). The key aspect of "learning advantages of newness" may be firms' ability to learn from various sources, including vicarious and congenital learning, to overcome limited experiential knowledge. We suggest that entrepreneurs of rapidly internationalizing SMEs use their network relationship and prior experience proactively, not only for acquiring knowledge but for internalizing it. Moreover, the flexibility of younger firms to improvise, experiment and explore in novel and uncertain markets fosters experiential learning (Zahra et al. 2018).

More broadly, our findings provide new insights into the value of network relationships for internationalization. Whilst they are recognized to be important at post-market entry stage, leveraging network learning can represent a middle ground between learning undertaken by firms operating relatively independently and those operating within joint ventures and other types of formal associations and networks. However, successful learning from external sources will depend on the firm's absorptive capacity (e.g., Cohen and Levinthal 1990) and should support pursuing and developing opportunities in the internationalizing firm. We would expect the firm's absorptive capacity to positively influence the capacity to acquire new knowledge, particularly from external sources. Therefore we argue that the presence of information from internal and external sources per se will not enable firms to maintain sufficient post-entry performance (Cohen and Levinthal 1990); the firm also must develop a learning orientation and appropriate learning capabilities. Managers must be mindful of the role and importance of learning competencies, processes, and mechanisms sufficient to acquire and internalize 
requisite knowledge not only for market entry but also for post-entry sustainable performance.

\subsection{Managerial and Policy Implications}

The findings of this study can help practitioners identify the important factors, and crucially the combination of these factors, which act to drive rapidly internationalizing SMEs post-entry performance. Managers need to pay attention to both internal sources of knowledge, as well as external sources such as attending international trade fairs, which can provide important learning opportunities for international market expansions. Relatedly, we argue that the firm would benefit from investing in training not only for the SME owner, in terms of understanding diverse contexts as the firm internationalizes, but widening such training for other employees of the firm, who, as we demonstrated, play proactive roles in developing knowledge within the contours of their firm.

Organizational learning is likely to be especially important in international business, where target markets, opportunities, and external environments feature substantial risk and uncertainty. The rise of new technologies-such as digital platforms, big data, the internet of things, artificial intelligence, and quantum computing - are leading to revolutionary methods, products and, indeed, potentially new industries; creating greater complexity and pressures for internationalizing firms. In the contemporary global business environment, organizational learning becomes more critical but also more challenging. Despite much uncertainty and fast-moving change, managers' fundamental ability to process information remains relatively constant and constrained by bounded rationality (Simon 1991).

Governments have an interest in promoting the sustainability and performance of internationalizing SMEs (Oparaocha 2015). Consequently, our findings suggest implications for policymakers through identifying the challenges of finding and internalizing internationalization-related information and knowledge. Policymakers should support SME internationalization by exposing such firms to international sources of knowledge in an effort to improving organizational performance and growth at the post-entry stage. Public policy can also emphasize programs that engender international opportunities through trade promotion, advocacy, matchmaker events, and other such activities. Therefore, policy can play a key role to support SME education regarding internationalization and sustainable foreign market performance.

\subsection{Limitations and Future Research Directions}

This research is subject to limitations which offer directions for future research. First, we adopted a qualitative approach from one core emerging market economy, India. These results may not be generalized to all early internationalizing SMEs. Future empirical studies should undertake a mixed-method approach and conduct a large-scale survey to test relationships between different learning strategies and 
post-market entry growth and development. Second, whilst India is one of the most representative emerging markets, this research should be extended to other emerging economies and industrial contexts, to help enhance the external validity of findings. We highlight the need for future research to better examine the role of micro-level individual actions on factors like collaborations with diverse networks. Hence, further studies on micro-foundational aspects, such as managerial skills, cognition and decision-making processes would enhance our understanding of the topic in question. Third, whilst this research identified the role of social capital as a bridging and bonding mechanism amongst and across SMEs through peer-to-peer learning, future research should examine to what extent peer-to-peer learning takes place between SME owners and employees within and across different firms, including channel partners. Fourth, there is scope to examine how rapidly internationalizing SMEs maintain diverse networks across different markets and how such networks facilitate capabilities for exploration and exploitation. Fifth, future studies could integrate an institution-based view with network perspectives and examine the post-entry growth and survival of SMEs from different institutional settings. Last, future studies could examine the role of learning in business model innovation of rapidly internationalizing SMEs.

Acknowledgements We would like to thank the two anonymous reviewers and Jeoung Yul Lee, the editor of this issue for their very useful comments. An earlier version of this paper was presented at the Academy of International Business UK and Ireland (AIB-UKI) 2019 conference held in University of Sussex, Brighton, UK, where it received the University of Birmingham best research methods paper award. We are also thankful to the AIB-UKI conference participants for their valuable comments.

Open Access This article is licensed under a Creative Commons Attribution 4.0 International License, which permits use, sharing, adaptation, distribution and reproduction in any medium or format, as long as you give appropriate credit to the original author(s) and the source, provide a link to the Creative Commons licence, and indicate if changes were made. The images or other third party material in this article are included in the article's Creative Commons licence, unless indicated otherwise in a credit line to the material. If material is not included in the article's Creative Commons licence and your intended use is not permitted by statutory regulation or exceeds the permitted use, you will need to obtain permission directly from the copyright holder. To view a copy of this licence, visit http://creativecommons.org/licen ses/by/4.0/.

\section{References}

Aldrich, H., \& Auster, E. R. (1986). Even dwarfs started small: Liabilities of age and size and their strategic implications. Research in Organizational Behavior, 8, 165-198.

Ansoff, H. I. (1957). Strategies for diversification. Harvard Business Review, 35(5), 113-124.

Argyris, C., \& Schön, D. A. (1996). Organizational learning II: Theory, method and practice. Reading: Addison-Wesley.

Arora, A., \& Gambardella, A. (1990). Complementary and external linkages: Strategies of the large firm in biotechnology. Journal of Industrial Economics, 38(4), 361-379.

Autio, E. (2005). Creative tension: the significance of Ben Oviatt's and Patricia McDougall's article 'toward a theory of international new ventures'. Journal of International Business Studies, 36(1), 9-19. 
Autio, E., George, G., \& Alexy, O. (2011). International entrepreneurship and capability developmentQualitative evidence and future research directions. Entrepreneurship Theory and Practice, 35(1), $11-37$.

Autio, E., Sapienza, H. J., \& Almeida, J. G. (2000). Effects of age at entry, knowledge intensity, and imitability on international growth. Academy of Management Journal, 43(5), 909-924.

Bierly, P., \& Chakrabarti, A. (1996). Generic knowledge strategies in the US pharmaceutical industry. Strategic Management Journal, 17, 123-135.

Bingham, C. B., \& Davis, J. P. (2012). Learning sequences: Their existence, effect, and evolution. Academy of Management Journal, 55(3), 611-641.

Birkinshaw, J., Brannen, M. Y., \& Tung, R. L. (2011). From a distance and generalizable to up close and grounded: Reclaiming a place for qualitative methods in international business research. Journal of International Business Studies, 42(5), 573-581.

Birkinshaw, J., \& Hood, N. (2000). Characteristics of foreign subsidiaries in industry clusters. Journal of International Business Studies, 31(1), 141-154.

Bruneel, J., Yli-Renko, H., \& Clarysse, B. (2010). Learning from experience and learning from others: How congenital and interorganizational learning substitute for experiential learning in young firm internationalization. Strategic Entrepreneurship Journal, 4(2), 164-182.

Chandra, Y. (2017). Social entrepreneurship as emancipatory work. Journal of Business Venturing, 32(6), 657-673.

Chandra, Y., Styles, C., \& Wilkinson, I. F. (2012). An opportunity-based view of rapid internationalization. Journal of International Marketing, 20(1), 74-102.

Child, J., \& Hsieh, L. H. (2014). Decision mode, information and network attachment in the internationalization of SMEs: A configurational and contingency analysis. Journal of World Business, 49(4), 598-610.

Child, J., Hsieh, L., Elbanna, S., Karmowska, J., Marinova, S., Puthusserry, P., et al. (2017). SME international business models: The role of context and experience. Journal of World Business, 52(5), 664-679.

Ciravegna, L., Lopez, L., \& Kundu, S. (2014). Country of origin and network effects on internationalization: A comparative study of SMEs from an emerging and developed economy. Journal of Business Research, 67(5), 916-923.

Ciszewska-Mlinarič, M., Wójcik, P., \& Obłój, K. (2019). Learning dynamics of rapidly internationalizing venture: Beyond the early stage of international growth in a CEE context. Journal of Business Research. https://doi.org/10.1016/j.jbusres.2019.03.002.

Clarysse, B., Wright, M., \& Van de Velde, E. (2011). Entrepreneurial origin, technological knowledge, and the growth of spin-off companies. Journal of Management Studies, 48(6), 1420-1442.

Cohen, W. M., \& Levinthal, D. A. (1990). Absorptive capacity: A new perspective on learning and innovation. Administrative Science Quarterly, 35(1), 128-152.

Coviello, N. E. (2006). The network dynamics of international new ventures. Journal of International Business Studies, 37(5), 713-731.

Coviello, N. (2015). Re-thinking research on born globals. Journal of International Business Studies, 46(1), 17-26.

Covin, J. G., \& Miller, D. (2014). International entrepreneurial orientation: Conceptual considerations, research themes, measurement issues, and future research directions. Entrepreneurship Theory and Practice, 38(1), 11-44.

Das, S., \& Das, A. (2014). India shining? A two-wave study of business constraints upon micro and small manufacturing firms in India. International Small Business Journal, 32(2), 180-203.

Davis, J. P., \& Eisenhardt, K. M. (2011). Rotating leadership and collaborative innovation: Recombination processes in symbiotic relationships. Administrative Science Quarterly, 56(2), 159-201.

De Clercq, D., Sapienza, H. J., Yavuz, R. I., \& Zhou, L. (2012). Learning and knowledge in early internationalization research: Past accomplishments and future directions. Journal of Business Venturing, $27(1), 143-165$.

De Clercq, D., \& Zhou, L. (2014). Entrepreneurial strategic posture and performance in foreign markets: The critical role of international learning effort. Journal of International Marketing, 22(2), 47-67.

Deligianni, I., Voudouris, I., \& Lioukas, S. (2015). Growth paths of small technology firms: The effects of different knowledge types over time. Journal of World Business, 50(3), 491-504.

Doz, Y. (2011). Qualitative research for international business. Journal of International Business Studies, $42(5), 582-590$. 
Eberhard, M., \& Craig, J. (2013). The evolving role of organisational and personal networks in international market venturing. Journal of World Business, 48(3), 385-397.

Economist. (2017). What is in a name? Defining emerging markets. https://www.economist.com/specialreport/2017/10/05/defining-emerging-markets. Accessed 5 Oct 2017.

Eisenhardt, K. M. (1989). Agency theory: An assessment and review. Academy of Management Review, 14(1), 57-74.

Eisenhardt, K., \& Martin, J. (2000). Dynamic capabilities: What are they? Strategic Management Journal, 21(10/11), 1105-1122.

Eriksson, K., Johanson, J., Majkgard, A., \& Sharma, D. D. (1997). Experiential knowledge and cost in the internationalization process. Journal of International Business Studies, 28(2), 337-360.

Evers, N., Andersson, S., \& Hannibal, M. (2012). Stakeholders and marketing capabilities in international new ventures: Evidence from Ireland, Sweden, and Denmark. Journal of International Marketing, 20(4), 46-71.

Evers, N., \& O'Gorman, C. (2011). Improvised internationalization in new ventures: The role of prior knowledge and networks. Entrepreneurship and Regional Development, 23(7-8), 549-574.

Fletcher, M., \& Harris, S. (2012). Knowledge acquisition for the internationalization of the smaller firm: Content and sources. International Business Review, 21(4), 631-647.

Fuerst, S., \& Zettinig, P. (2015). Knowledge creation dynamics with in the international new venture. European Business Review, 27(2), 182-213.

Gabrielsson, M., Kirpalani, V. H. M., Dimitratos, P., Solberg, C. A., \& Zucchella, A. (2008). Born globals: Propositions to help advance the theory. International Business Review, 17(4), 385-401.

Gabrielsson, P., \& Gabrielsson, M. (2013). A dynamic model of growth phases and survival in international business-to-business new ventures: The moderating effect of decision-making logic. Industrial Marketing Management, 42(8), 1357-1373.

Galkina, T., \& Chetty, S. (2015). Effectuation and networking of internationalizing SMEs. Management International Review, 55(5), 647-676.

George, G., Wiklund, J., \& Zahra, S. A. (2005). Ownership and the internationalization of small firms. Journal of Management, 31(2), 210-233.

Gerschewski, S., Lew, Y. K., Khan, Z., \& Park, B. I. (2018). Post-entry performance of international new ventures: The mediating role of learning orientation. International Small Business Journal, 36(7), $807-828$.

Hånell, S. M., \& Ghauri, P. N. (2016). Internationalization of smaller firms: Opportunity development through networks. Thunderbird International Business Review, 58(5), 465-477.

Hanvanich, S., Sivakumar, K., \& Hult, G. (2006). The relationship of learning and memory with organizational performance: The moderating role of turbulence. Journal of the Academy of Marketing Science, 34(4), 600-612.

Hartman, E., Tower, C., \& Sebora, T. (1994). Information sources and their relationship to organizational innovation in small business. Journal of Small Business Management, 32(1), 10-25.

Hsieh, L., Child, J., Narooz, R., Elbanna, S., Karmowska, J., Marinova, S., et al. (2019). A multidimensional perspective of SME internationalization speed: The influence of entrepreneurial characteristics. International Business Review, 28(2), 268-283.

Huber, G. (1991). Organizational learning: The contributing processes and literature. Organization Science, 2(1), 88-115.

Ibeh, K., Jones, M. V., \& Kuivalainen, O. (2018). Consolidating and advancing knowledge on the postentry performance of international new ventures. International Small Business Journal, 36(7), 741-757.

Inkpen, A. C., \& Tsang, E. W. (2005). Social capital, networks, and knowledge transfer. Academy of Management Review, 30(1), 146-165.

Johanson, J., \& Vahlne, J.-E. (1977). The internationalization process of the firm-A model of knowledge development and increasing foreign market commitments. Journal of International Business Studies, 8(1), 23-32.

Johanson, J., \& Vahlne, J. E. (2006). Commitment and opportunity development in the internationalization process: A note on the Uppsala internationalization process model. Management International Review, 46(2), 165-178.

Johanson, J., \& Vahlne, J. E. (2009). The Uppsala internationalization process model revisited: From liability of foreignness to liability of outsidership. Journal of international Business Studies, 40(9), 1411-1431. 
Khan, Z., \& Lew, Y. K. (2018). Post-entry survival of developing economy international new ventures: A dynamic capability perspective. International Business Review, 27(1), 149-160.

Khan, Z., Rao-Nicholson, R., \& Tarba, S. Y. (2018). Global networks as a mode of balance for exploratory innovations in a late liberalizing economy. Journal of World Business, 53(3), 392-402.

Kim, J. Y., \& Miner, A. S. (2007). Vicarious learning from the failures and near-failures of others: Evidence from the US commercial banking industry. Academy of Management Journal, 50(3), $687-714$.

Kiss, A., Danis, W., \& Cavusgil, S. T. (2012). International entrepreneurship research in emerging economies: A critical review and research agenda. Journal of Business Venturing, 27(2), 266-290.

Knight, G. A., \& Cavusgil, S. T. (2004). Innovation, organizational capabilities, and the born-global firm. Journal of International Business Studies, 35(2), 124-141.

Knight, G. A., \& Liesch, P. W. (2016). Internationalization: From incremental to born global. Journal of World Business, 51(1), 93-102.

Kuivalainen, O., Sundqvist, S., \& Servais, P. (2007). Firms' degree of born-globalness, international entrepreneurial orientation and export performance. Journal of World Business, 42(3), 253-267.

Lee, T. W. (1999). Using qualitative methods in organizational research. Thousand Oaks: Sage Publications.

Li, P. F. (2014). Global temporary networks of clusters: Structures and dynamics of trade fairs in Asian economies. Journal of Economic Geography, 14(5), 995-1021.

Lincoln, Y. S., \& Guba, E. G. (1985). Naturalistic inquiry. Newbury Park: Sage Publications Inc.

Luo, Y. (2001). Determinants of local responsiveness: Perspectives from foreign subsidiaries in an emerging market. Journal of Management, 27(4), 451-477.

Madsen, P. M., \& Desai, V. (2010). Failing to learn? The effects of failure and success on organizational learning in the global orbital launch vehicle industry. Academy of Management Journal, 53(3), 451-476.

March, J. G. (1991). Exploration and exploitation in organizational learning. Organization Science, 2(1), 71-87.

Marshall, B., Cardon, P., Podder, A., \& Fontenot, R. (2013). Does sample size matter in qualitative research? A review of qualitative interviews in IS research. Journal of Computer Information Systems, 54(1), 11-22.

Maskell, P. (2014). Accessing remote knowledge-the roles of trade fairs, pipelines, crowdsourcing and listening posts. Journal of Economic Geography, 14(5), 883-902.

Maskell, P., Bathelt, H., \& Malmberg, A. (2006). Building global knowledge pipelines: The role of temporary clusters. European Planning Studies, 14(8), 997-1013.

Mason, J. (2017). Qualitative researching (3rd ed.). Thousand Oaks: Sage Publications Inc.

McKelvie, A., \& Wiklund, J. (2010). Advancing firm growth research: A focus on growth mode instead of growth rate. Entrepreneurship Theory And Practice, 34(2), 261-288.

Measson, N., \& Campbell-Hunt, C. (2015). How SMEs use trade shows to enter global value Chains. Journal of Small Business and Enterprise Development, 22(1), 99-126.

Miles, M. B., \& Huberman, A. M. (1994). Qualitative data analysis: An expanded sourcebook (2nd ed.). Thousand Oaks: Sage Publications.

Mody, A. (1993). Learning through alliances. Journal of Economic Behavior and Organization, 20(2), 151-170.

Mort, G., \& Weerawardena, J. (2006). Networking capability and international entrepreneurship: How networks function in Australian born global firms. International Marketing Review, 23(5), 549-572.

NASSCOM. (2017). The IT-BPM sector in India: Strategic review 2017. New Delhi: NASSCOM.

Oparaocha, G. O. (2015). SMEs and international entrepreneurship: An institutional network perspective. International Business Review, 24(5), 861-873.

Oviatt, B. M., \& McDougall, P. (1994). Toward a theory of international new ventures. Journal of International Business Studies, 25, 45-64.

Oviatt, B., \& McDougall, P. (2005). Defining international entrepreneurship and modeling the speed of internationalization. Entrepreneurship Theory and Practice, 29(5), 537-554.

Park, J. Y., Ha, Y. J., \& Lew, Y. K. (2015). International joint ventures and dynamic co-learning between MNEs and local firms. In P. Konara, Y. J. Ha, F. McDonald, \& Y. Wei (Eds.), The rise of multinationals from emerging economies (pp. 213-225). London: Palgrave Macmillan.

Park, T., \& Rhee, J. (2012). Antecedents of knowledge competency and performance in born globals: The moderating effects of absorptive capacity. Management Decision, 50(8), 1361-1381. 
Patton, M. Q. (1990). Qualitative evaluation and research methods (2nd ed.). Thousand Oaks: Sage Publications Inc.

Pellegrino, J., \& McNaughton, R. (2015). The co-evolution of learning and internationalization strategy in international new ventures. Management International Review, 55(4), 457-483.

Pellegrino, J. M., \& McNaughton, R. B. (2017). Beyond learning by experience: The use of alternative learning processes by incrementally and rapidly internationalizing SMEs. International Business Review, 26(4), 614-627.

Powell, W., Koput, K., \& Smith-Doerr, L. (1996). Interorganizational collaboration and the locus of innovation: Networks of learning in biotechnology. Administrative Science Quarterly, 41(1), $116-145$.

Prashantham, S., \& Dhanaraj, C. (2010). The dynamic influence of social capital on the international growth of new ventures. Journal of Management Studies, 47(6), 967-994.

Prashantham, S., \& Young, S. (2011). Post-entry speed of international new ventures. Entrepreneurship Theory and Practice, 35(2), 275-292.

Presutti, M., Boari, C., \& Fratocchi, L. (2007). Knowledge acquisition and the foreign development of high-tech start-ups: A social capital approach. International Business Review, 16(1), 23-46.

Reagans, R., \& McEvily, B. (2003). Network structure and knowledge transfer: The effects of cohesion and range. Administrative Science Quarterly, 48(2), 240-267.

Romanello, R., \& Chiarvesio, M. (2017). Turning point: when born globals enter post-entry stage. Journal of International Entrepreneurship, 15(2), 177-206.

Salavisa, I., Sousa, C., \& Fontes, M. (2012). Topologies of innovation networks in knowledge-intensive sectors: Sectoral differences in the access to knowledge and complementary assets through formal and informal ties. Technovation, 32(6), 380-399.

Sardana, D., \& Scott-Kemmis, D. (2010). Who learns what?-A study based on entrepreneurs from biotechnology new ventures. Journal of Small Business Management, 48(3), 441-468.

Simon, H. (1991). Bounded rationality and organizational learning. Organizational Science, 2(1), $125-135$.

Sinkula, J., Baker, W., \& Noordewier, T. (1997). A framework for market-based organizational learning: Linking values, knowledge and behaviour. Journal of the Academy of Marketing Science, 25(4), $305-318$.

Sleuwaegen, L., \& Onkelinx, J. (2014). International commitment, post-entry growth and survival of international new ventures. Journal of Business Venturing, 29(1), 106-120.

Sullivan, D. M., \& Marvel, M. R. (2011). Knowledge acquisition, network reliance, and early-stage technology venture outcomes. Journal of Management Studies, 48(6), 1169-1193.

Sullivan-Mort, G., \& Weerawardena, J. (2006). Networking capability and international entrepreneurship: How networks function in Australian born global firms. International Marketing Review, 23(5), 549-572.

Teece, D., Pisano, G., \& Shuen, A. (1997). Dynamic capabilities and strategic management. Strategic Management Journal, 18(7), 509-533.

Trudgen, R., \& Freeman, S. (2014). Measuring the performance of born-global firms throughout their development process: The roles of initial market selection and internationalisation speed. Management International Review, 54(4), 551-579.

Tuomisalo, T., \& Leppäaho, T. (2019). Learning in international new ventures: A systematic review. International Business Review, 28(3), 463-481.

Weerawardena, J., Mort, G., Salunke, S., Knight, G., \& Liesch, P. (2015). The role of the market subsystem and the socio-technical sub-system in innovation and early internationalization: A dynamic capabilities approach. Journal of the Academy of Marketing Science, 43(2), 221-239.

Yin, R. K. (2009). Case study research: Design and methods. Thousand Oaks: Sage Publications.

Yu, J., Gilbert, B. A., \& Oviatt, B. M. (2011). Effects of alliances, time, and network cohesion on the initiation of foreign sales by new ventures. Strategic Management Journal, 32(4), 424-446.

Zahra, S. A., Ireland, R. D., \& Hitt, M. A. (2000). International expansion by new venture firms: International diversity, mode of market entry, technological learning, and performance. Academy of Management Journal, 43(5), 925-950.

Zahra, S. A., Zheng, C., \& Yu, J. (2018). Learning advantages of newness: A reconceptualization and contingent framework. Journal of International Entrepreneurship, 16(1), 12-37.

Zhou, L., Barnes, B., \& Lu, Y. (2010). Entrepreneurial proclivity, capability upgrading and performance advantage of newness among international new ventures. Journal of International Business Studies, 41(5), 882-905. 
Zou, H., \& Ghauri, P. N. (2010). Internationalizing by learning: The case of Chinese high-tech new ventures. International Marketing Review, 27(2), 223-244.

Publisher's Note Springer Nature remains neutral with regard to jurisdictional claims in published maps and institutional affiliations.

\section{Affiliations}

\section{Pushyarag Puthusserry ${ }^{1}\left([) \cdot\right.$ Zaheer Khan $^{2,3}\left([) \cdot\right.$ Gary Knight $^{2,4} \cdot$ Kristel Miller $^{5}$}

1 Kent Business School, University of Kent, Canterbury, UK

2 University of Aberdeen Business School, University of Aberdeen, Aberdeen, Scotland, UK

3 The School of Marketing and Communication, University of Vaasa, Vaasa, Finland

4 Atkinson Graduate School of Management, Willamette University, Salem, OR, USA

5 Ulster University Business School, University of Ulster, Belfast, UK 